\title{
Students' Difficulties in Comprehending Narrative Text
}

\author{
Aulia Khoirunnisa \\ Universitas Muhammadiyah Malang, Indonesia. \\ auliakh4@gmail.com \\ Estu Widodo \\ Universitas Muhammadiyah Malang, Indonesia. \\ estu_wid@yahoo.com
}

\begin{abstract}
Reading skill has been found to be one of difficult skills to achieve for many learners of English as a Foreign Language (EFL). Importantly, based on the preliminary study, narrative texts are deemed to be difficult. This study was conducted to investigate the students' difficulties in reading text at a private primary school in Batu, involving 29 ninth grade students in the academic year of 2018-2019 as the samples. Employing the purposive sampling method by which the best class was selected, the researcher used10-items of a closed-ended questionnaire to collect the data. In the analysis, some aspects of the narrative text such as words, structure, language feature, character, setting, plot, moral value, and point of view were highlighted. Consistently, narrative texts were found to be the most difficult text faced by students at school. According to the English teacher, students got the difficulties because of lack of vocabulary, the use of simple past tense, and the instruction to make sense of the moral values. Further, difficulties pertain to the effort to comprehend the structure, point of view, and the words.
\end{abstract}

Key words: students' difficulties, reading skill, narrative text

\section{Introduction}

Regardless the importance of English skills, reading seems to be the main key as the significant skill that should be the main concern. The success of language learner is largely influenced by his/her reading practice. As stated by Harmer (2007:99), reading is useful for language acquisition: "the more they read, the better they get".

The importance of reading is also realized by the Indonesian government. They decides to include English in the nation-wide school curriculum and make it the compulsory subject at schools. Moreover, reading is tested at the national examination.

English reading becomes complicated for students because English is not their mother tongue, so most of them still find difficulties in reading comprehension. That is evident that English language achievement in Indonesian school is still low. In fact, Programme for International 
Khoirunnisa, Widodo

TELL: Teaching of English Language and Literature Journal

Vol. 7, No 2, September 2019, DOI http://dx.doi.org/10.30651/tell.v7i2.3441

Students Assessment (PISA) 2015 shows that 15-year-old Indonesian students rank the lowest in basic reading skill compared to their peers in other countries.

Then, based on Education First (EF) 2018, English proficiency index of Indonesia in the low position along with 20 other countries. The Indonesian student average value is 51.58 , in the $51^{\text {st }}$ rank among 88 countries.

Indonesian high school students are required to master several kinds of texts such as descriptive, recount, report, procedure and narrative texts. A narrative text is the most interesting text to learn compared with others, since the text's purpose is to amuse the readers. Miller (2007) states that problems, actions, resolutions, and solutions are the structure of the narrative text. Additionally, according to Nadine (2012:79), narrative text tells the readers about the events that happened in the past times, which include fable, legend, and folktale.

It can be said that, besides narrative is an interesting text, it is also the complicated text. There are several things considered in comprehending narrative text, such as the elements of text, the text comprehension, the words analysis, etc. compared with the others type of text, the language feature and generic structure of narrative text are more complex. Additionally, students' previous knowledge such as grammar, vocabulary, and background knowledge influence their reading achievement as well.

The description above is in line with the statement of an English teacher that researcher got during internship in SMP Manalagi Batu. From the interview to the English teacher of ninth grade students, among 5 types of texts in the junior high school, narrative text is the most complicated text faced by students. According to him, students in the ninth grade have lack of vocabulary; moreover, the simple past tense is used in narrative text and finding the moral value of narrative text proves to be difficult for them. The evidence can be seen from the scores of students learning outcomes (see appendix 1).

Based on the situation, the researcher decides to do the study at SMP Manalagi Batu to find out the students' difficulties in reading narrative texts.

\section{Literature Review}

\section{Reading Comprehension}

Reading cannot be separated from comprehension because the purpose or the result of reading activity to comprehend what has been read. Reading without understanding what has been read is useless. Mukhroji (2011:57), states that 'reading comprehension is a process of getting information from context and combining schema to interpret text in order to construct meaning'.

In line with the idea Snow (2010:413) point out that reading comprehension is a process of forming and obtaining meaningful information through interaction and use of print media.

This definition emphasizes that reading comprehension is the process of creating meaning from discourse, which aims to gain a full understanding of what is described in the text, not just from understanding the meaning of a limited word or sentence in the text.

Students' Difficulties in Comprehending Narrative Text 
According to Cohen (2000), in narrative text, the students should find the main ideas or contents of Orientation, Complication, Resolution and Reorientation. In Orientation the students need to know the scene and the participants. Then, in complication, the students should find the problems occur in the story. For the resolution, the students will find how the problems are solved. Last, reorientation refers to the conclusion of a story.

Harmer (2007:16) states that grammar of language is the description of the ways in which words can change their forms and can be combined into sentences in that language. It can be said that to comprehending sentences of the narrative text, the students should master the grammar of narrative text like the structure, language feature, and adverb of time used in the text.

Besides that, vocabulary must be the other cause of the problem in comprehending a text. It is not easy for the students to find certain word meaning from the text. As a result, they might not be able to find the detail information from the text. According to Olson and Diller (1982:42), what is meant by comprehending narrative text is a term used to identify those skills needed to understand and apply information contained in a written material. It means that the students should be able to know the information in narrative text.

In other words, it is not easy for the students to comprehend a narrative text. They have to recognize, all the elements of the text such orientation, complication, resolution and reorientation, the grammar, also the vocabulary.

\section{Reading Comprehension at Junior High Schools}

At junior high schools, teaching reading is intended to further students' skill in reading comprehension. Based on the basic competence of the Currriculum 2013, the students are expected to be able to comprehend the content of English text. However, in a real situation, the students do not achieve the curriculum expectation and have lower ability in reading comprehension.

The Generic Structure of Narrative Text

In order to understand the narrative text, other aspects of the text have to be considered, that is the generic structure and language features. According to Anderson (2003:8), the steps for constructing the narrative including (1) an orientation in which the narrator tells the audience about who is in the story, when the story is taking place, and where the action is happening, (2) a complication that sets off a chain of events that influence what will happen in the story, (3) a sequence of events where the characters react to the complication, (4) a resolution in which the characters finally solve the complication, (5) a coda that provides a comment or moral based on what has been learned from the story.

Moreover, the language features that are usually found in a narrative are past tense, and adverb of time that only found in narrative as once upon a time, one day, etc. additional according to Anderson (2003:8), are specific characters, time words that connect events to tell when they occur, verbs to show the actions that occur in the story, descriptive words to portray the characters and setting.

In brief, generic structures in narrative text are orientation, complication, events, resolution, and moral value. Then, language features of narrative text are past tense, adverb of 
Khoirunnisa, Widodo

TELL: Teaching of English Language and Literature Journal

Vol. 7, No 2, September 2019, DOI http://dx.doi.org/10.30651/tell.v7i2.3441

time, time conjunction, specific character, action verbs and direct speech. The most important, should be considered that many component must be learned to comprehend the narrative text.

According to Haris (2010), there are some features the students should comprehend in narrative text; (1) Plot: What is going to happen? (2) Setting: Where will the story take place? When will the story take place? (3) Characterization: Who are the main characters? What do they look like? (4) Structure: How will the story begin? What will be the problem? How is the problem going to be resolved? (5) Theme: What is the theme/message the writer is attempting to communicate?

\section{Methodology}

In this study, the researcher used quantitative research approach and chose case study to use. The population was the 125 students in ninth grade at SMP Manalagi Batu. The samples were 29 students of the ninth grade.

To get the survey data the researcher employed a closed-ended questionnaire.

\section{Findings and Discussion}

The results of the questionnaire showed that students faced some difficulties in comprehending reading narrative texts. From the 10 questions in the questionnaire, the researcher found eight difficulties faced by students: difficulties dealing with grammar, point of view, majority of words, meaning of each sentence, moral value, information finding, and plot. Then, from the result of closed-end questionnaire, the difficulties were related to the comprehending of the structure, point of view, and majority of words. These difficulties were dominantly found. The total number of students who got difficulty in comprehending structure is $86 \%$; point of view and majority of words, $76 \%$.

1) Students' Difficulties in Comprehending Grammar of Narrative Text

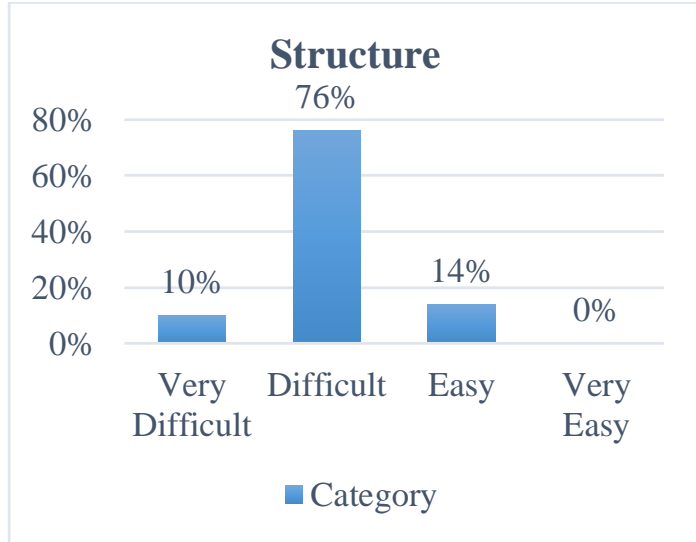

Fig. 1. Students' Difficulties in Comprehending Grammar

In the result of closed-ended questionnaire, comprehending the grammar was found to be the most dominant problem that students faced. The table shows that more than half of the students, accounted for $76 \%$ students got difficulty and $10 \%$ students felt very difficult in comprehending 
structure of narrative text. Thus, total students who had difficulty in comprehending grammar were 86\%. It was because students' first language is different with English, which is grammar based. They rarely used grammar in the daily life.

According to Matsunaga \& Koda (2010) study, EFL learners need knowledge of grammar to comprehend the meaning of text. The reading comprehension of students is based on the grammar skill among them. Student who have lack of grammatical knowledge must be have difficulty in construct the meaning of text. Thus, their study showed that there is a significant relationship between grammar knowledge and reading comprehension. It can be said that the difficulties in comprehending structure can be caused by students' first language, which is Indonesian or Javanese language, and no extensive exposure to English grammar since they were kids. In this case, the students must master the generic structures to comprehend narrative text. Language feature in narrative text is different from others texts, which is using the simple past tense. If the students did not master simple present tense, they would feel difficult to master the simple past tense. Thus, they may feel that structure can cause any difficulties in reading.

2) Students Difficulties in Comprehending Point of View of Narrative Text

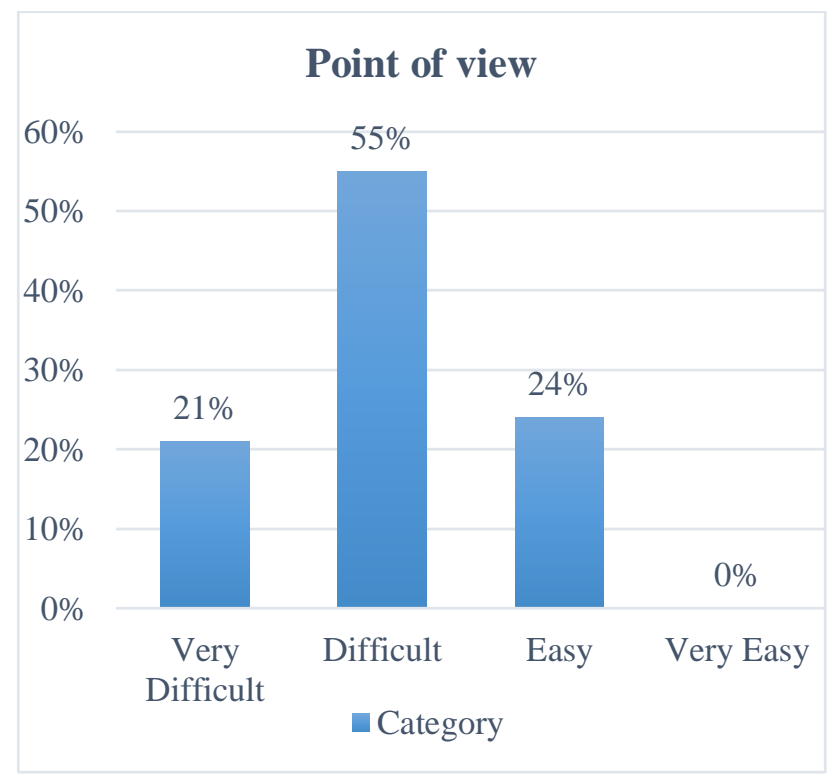

Fig.2. Students' Difficulties in Comprehending the Point of View

As we can see, the total of students who got difficulty in comprehending point of view was also high; $76 \%$ of 29 students. Only $24 \%$ students did not get difficulty in finding point of view of the narrative text. It can be said that the students have problem to understand the types of point of view. Point of view can be interpreted as the position or placement of writers in the story. There are two types of point of view, they are first person point of view, and third person point of view. To comprehend the point of view in the text, the readers should be able to recognize types of point of view such as first person peripheral, third person limited, third person multiple, and third person 
Khoirunnisa, Widodo

TELL: Teaching of English Language and Literature Journal

Vol. 7, No 2, September 2019, DOI http://dx.doi.org/10.30651/tell.v7i2.3441

Omniscient. The findings of this study is different from those of the previous study conducted by Novia Fanny (2017) in which the students faced difficulty because they were not motivated to read. Most of them admitted that they could understand the narrative text which they are interested in.

3) Students Difficulties in Comprehending Majority of Words of Narrative Text

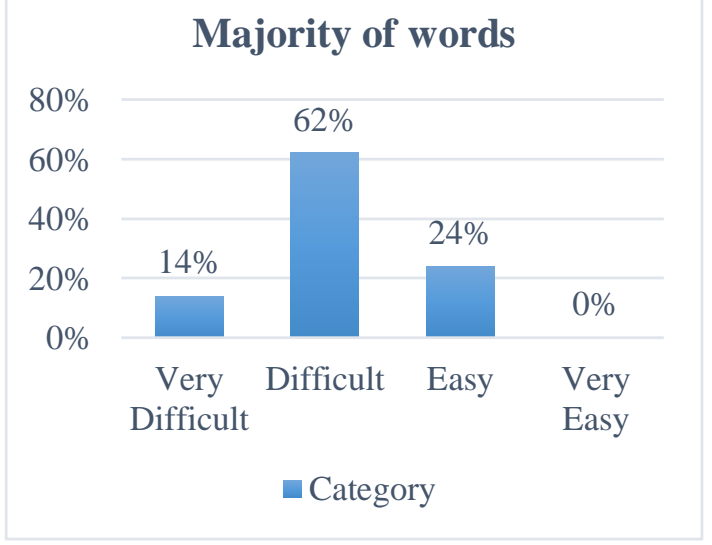

Fig.3. Students' Difficulties in Comprehending the Majority of Words

The figure shows that from all of the students, $76 \%$ students got difficulties in comprehending the majority of words in narrative text, and the rest of the students did not find any difficulty in comprehending words. Moreover, none of the students assumed that it was very easy.

If readers cannot understand the words, they will not be able to get the main idea or information on the text. It means that readers should master vocabularies, because vocabulary is the initial stage to learn before learning other aspects of language such as structure and pronunciation. Nation \& Waring (1997) state that learners require to know a minimum of 3000 words, because it represents $95 \%$ of text. In a study conducted by Rashidi N (2010), the role of breadth and depth of vocabulary knowledge in reading comprehension was investigated. The Word Associates Test and the Vocabulary Levels Test were administered to 38 senior university students for assessing depth and breadth of vocabulary knowledge respectively. Findings suggest interrelation among depth, breadth and reading comprehension performance with a positive correlation of 0.87 between the scores on the Word Associates Test and reading comprehension test, and also a positive correlation of 0.75 between the scores on the Vocabulary Levels Test and reading comprehension test. Students with stronger depth and breadth of vocabulary performed better in reading comprehension test. 
4) Students Difficulties in Relating Meaning of Each Sentence of Narrative Text

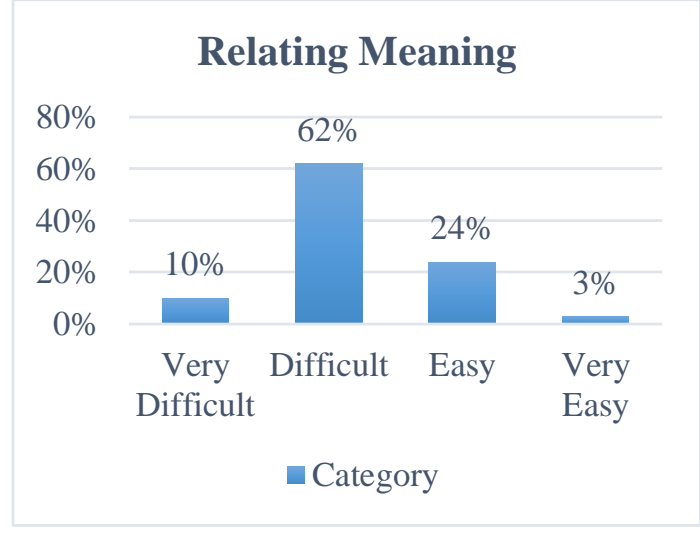

Fig.4. Students' Difficulties in Relating Meaning of Each Sentence

Based on the figure above, most respondents (62\%) felt difficult, $24 \%$ felt easy, $10 \%$ felt very difficult, and the rest $3 \%$ felt very easy. The difficulties related to the meaning of each sentence are caused by the fact that students cannot understand the smaller units of text, which are the words, sentences, or paragraphs.

5) Students Difficulties in Comprehending Moral Value of Narrative Text

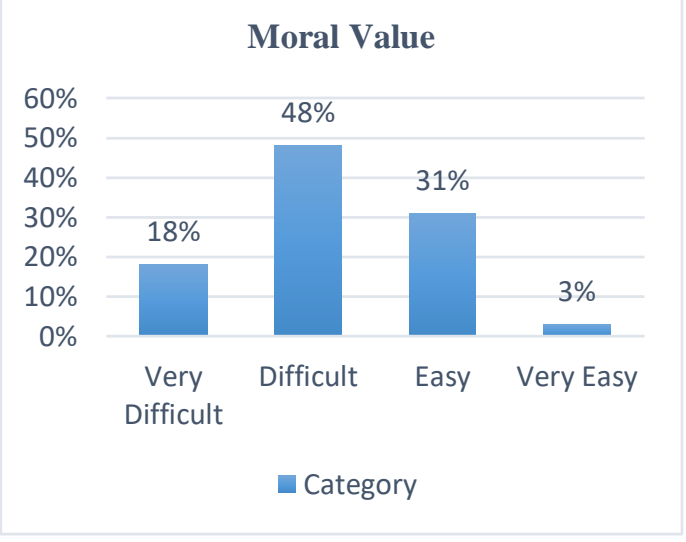

Fig.5. Students' Difficulties in Comprehending Moral Values

As shown in the figure 4.1.1.5, students who can read narrative text rapidly were only $34 \%$ students. According to the data, students who had difficulty in comprehending moral value more than half students, which were 19 students or $66 \%$ from 29 participating students. Since they cannot understand the text well, it is hard for them to find the moral value. 
Khoirunnisa, Widodo

TELL: Teaching of English Language and Literature Journal

Vol. 7, No 2, September 2019, DOI http://dx.doi.org/10.30651/tell.v7i2.3441

6) Students Difficulties in Comprehending the Information of Narrative Text

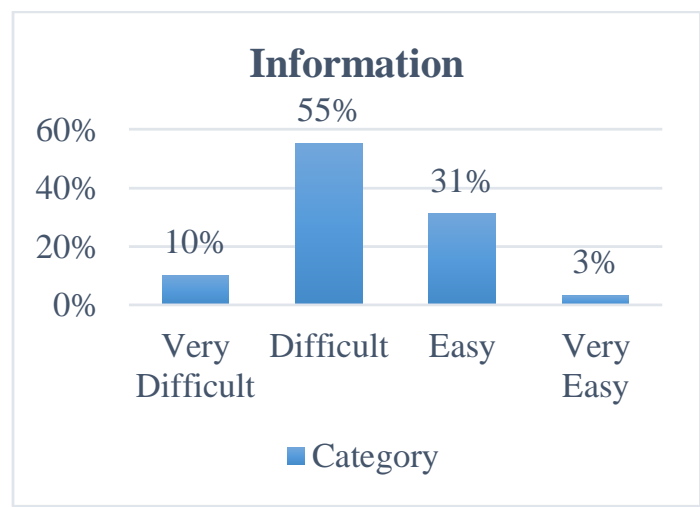

Fig.6. Students' Difficulties in Comprehending Information

The total students who got difficulty in comprehending information of text was $65 \%$. Less than half of the students comprehend the information easily (34\%). If the students do not comprehend the meaning of the text deeply, they will find the difficulties in finding the information of the text.

7) Students Difficulties in Comprehending the Plot of Narrative Text

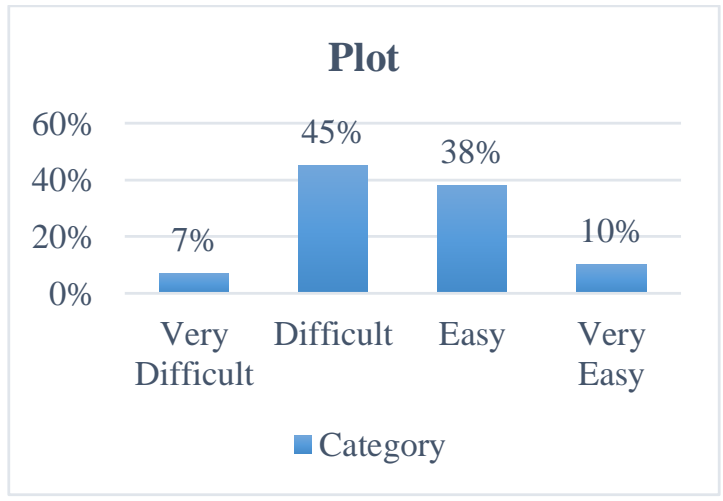

Fig.7. Students' Difficulties in comprehending the plot

From the figure 4.1.1.7 above, 52\% of 29 participants assumed that comprehending the plot was difficult task, while $48 \%$ assumed that it was easy. Thus, the students who had difficulty and the students who felt easy in comprehending the plot were relatively equal; half of students were able to retell the story in the correct order, while the others were not because they did not understand the point of the text.

\section{Conclusion and Suggestion}

The result shows that these students from the best class among the four ninth grade classes had the difficulties in reading comprehension. Referring to the data gained from questionnaire, it can be concluded that ninth grade students get difficulties in comprehending narrative texts. The 
most difficult things students faced in reading narrative text are comprehending the structure, point of view, and majority of words.

For suggestions, the teacher should pay attention to students' background knowledge, by providing them with the basic materials before giving more difficult ones. Then, the teacher should give more teaching and exercise in vocabulary so that it would be easier for the students to comprehend the text. The teacher should improve the students' grammatical knowledge as well as use interesting methods that make learning fun and finally get rid of the difficulties in comprehending academic texts.

\section{References}

Adas, D., \& Bakir, A. (2013). Writing Difficulties and New Solutions : Blended Learning as an Approach to Improve Writing Abilities PhD in teaching English Language Methods, ALQuds Open University ,. International Journal of Humanities and Social Science.

Aliaga and Gunderson. (2005). Quantitative and Qualitative Research Methods | SkillsYouNeed. Skills You Need.

Arikunto. (2010). Prosedur penelitian suatu pendekatan praktik. Jakarta, Rineka Cipta.

Arora, R., \& Stoner, C. (2009). A mixed method approach to understanding brand personality. Journal of Product and Brand Management. https://doi.org/10.1108/10610420910972792

Ary, D., Jacobs, L. C., Sorensen, C. K., Walker, D. A., \& Razavieh, A. (2010). Defining and designing qualitative research. In Introduction to Research in Education. https://doi.org/10.1017/CBO9781107415324.004

Harmer, J. (2007). How to Teach English. Education.

Ikah Atikah (2013). Analysis on the Studentsâ Problems in Comprehending Narrative Texts. Jurnal Pendidikan Dan Pembelajaran, 2(11).

Kartikawijaya, S.-. (2017). an Analysis of the Students' Reading Comprehension in Comprehending Descriptive Text. Curricula, 2(3), 80-87. https://doi.org/10.22216/jcc.2017.v2i3.2695

Matsunaga, S., \& Koda, K. (2010). Insights into Second Language Reading: A Cross-Linguistic Approach. Japanese Language and Literature. https://doi.org/10.2307/30198000

Miller, A. C., \& Keenan, J. M. (2009). How word decoding skill impacts text memory: The centrality deficit and how domain knowledge can compensate. Annals of Dyslexia. https://doi.org/10.1007/s11881-009-0025-x

Miller, E. R. (2007). Review of Beyond the beginnings: Literacy interventions for upper elementary English language learners. International Journal of Bilingual Education and Bilingualism. 
Khoirunnisa, Widodo

TELL: Teaching of English Language and Literature Journal

Vol. 7, No 2, September 2019, DOI http://dx.doi.org/10.30651/tell.v7i2.3441

https://doi.org/10.2167/bebb112.0

Mohamad Nor, N., \& Rashid, R. A. (2018). A review of theoretical perspectives on language learning and acquisition. Kasetsart Journal of Social Sciences. https://doi.org/10.1016/j.kjss.2017.12.012

Nadine. (2012). Metode the King Bahasa Inggris. Jakarta: Wahyumedia.

Nation, P., \& Waring, R. (1997). Vocabulary Size, Text Coverage and Word Lists. Vocabulary: Description, Acquisition and Pedagogy. https://doi.org/10.1017/CBO9781107415324.004

Rashidi N. (2010). Assessing the role of depth and breadth of vocabulary knowledge in reading comprehension of Iranian EFL learners. Journal of Pan-Pacific Assosiation of Applied Linguistics, 14(1).

Simanek, D. E. (2014). The measure of pi. The Physics Teacher. https://doi.org/10.1119/1.4862097

Snow, C. E. (2010). Reading comprehension: Reading for learning. In International Encyclopedia of Education. https://doi.org/10.1016/B978-0-08-044894-7.00511-X

Souhila, R. (2009). Analysis on the Students' Linguistic Problems in Reading Comprehension, 162.

Terrell, T. D., \& Brown, H. D. (2006). Principles of Language Learning and Teaching. Language. https://doi.org/10.2307/414380

Tight, M., VanWynsberghe, R., Khan, S., VanWynsberghe, R., \& Khan, S. (2016). Redefining Case Study. In Case Studies. https://doi.org/10.4135/9781473915480.n9 